University of Rhode Island

DigitalCommons@URI

The Rhode Island Current Conditions Index

Economics

$1-2009$

\title{
Rhode Island Current Conditions Index - January 2009
}

Leonard Lardaro

University of Rhode Island, lardaro@uri.edu

Follow this and additional works at: https://digitalcommons.uri.edu/ricci

Part of the Econometrics Commons

Terms of Use

All rights reserved under copyright.

\section{Recommended Citation}

Lardaro, Leonard, "Rhode Island Current Conditions Index - January 2009" (2009). The Rhode Island Current Conditions Index. Paper 37.

https://digitalcommons.uri.edu/ricci/37

This Article is brought to you for free and open access by the Economics at DigitalCommons@URI. It has been accepted for inclusion in The Rhode Island Current Conditions Index by an authorized administrator of DigitalCommons@URI.For more information, please contact digitalcommons-group@uri.edu. 
Rhode Island started 2009 with two bits of good news. The first is that 2008 is at long last over. If my expectation is correct, the fourth quarter of last year will prove to have been the most rapid rate of decline we will ultimately see. That's not to say, of course, that declining activity won't continue here clearly it will throughout this entire year. Second, the value of the Current Conditions Index for January was 17, based on two indicators improving relative to last January. As bad as that is, it is still a higher value than any we saw in all of 2008 and is consistent (for now at least) with my expectation of slower rates of decline in economic activity for this year.

As expected, the labor market data revisions didn't cause any dramatic changes to the originally published $\mathrm{CCl}$ values. The sole exception occurred in October, where the original value of 8 for that month (based on an improving Manufacturing Wage) disappeared, giving us a third value of 0 for 2008 and for any time since 1980! While my prediction that December's Unemployment Rate would be revised down from 10 to 9.4

\begin{tabular}{lc}
\multicolumn{2}{c}{ CCI I ndicators - \% Change } \\
Government Employment & -2.3 \\
US Consumer Sentiment & -22.1 \\
Single-Unit Permits & -59.5 \\
Retail Sales & -3.3 \\
Employment Services J obs & -22.3 \\
Priv. Serv-Prod Employment & -2.7 \\
Total Manufacturing Hours & -10.7 \\
Manufacturing Wage & 0.1 Y \\
Labor Force & -1.1 \\
Benefit Exhaustions & 40.2 \\
New Claims & -3.3 Y \\
Unemployment Rate & 63.5 \\
\multicolumn{1}{|c}{ Y = I mproved Value } &
\end{tabular}

percent was correct, my hope was that it would take a couple of months for us to get (back) to double digits. No such luck! The Unemployment Rate for January was 10.3 percent, a full four percentage points higher than its value one year ago. Is it good news that this horrific Unemployment Rate now gives us a national rank of \#3 (behind Michigan and South Carolina)? Your answer to this question will define the degree of desperation you find our state's economy to be in. And, the rise in our Unemployment Rate occurred as our Labor Force continued its string of declines (-1.1\% in January).

There were three pieces of "good" news for January. The first was that the Manufacturing Wage increased again, as it has for most of the last year. Its slow rate of increase, 0.1 percent, was partly the result of a difficult "comp," where its rate of increase was 3.9 percent last January. Ironically, this occurred as the rate of deterioration in our state's manufacturing sector continued to accelerate. For January, Total Manufacturing Hours plunged by 10.7 percent, its second double-digit decline, the result of sharp declines in both employment and the length of the workweek. Second, New Claims for Unemployment Insurance, a leading labor market indicator which reflects layoffs, improved for the first time since last July (by 3.3\%). Third, Single-Unit Permits, which indicates new home construction plunged to only 26 permits for the entire state (a fall of $59.5 \%$ compared to the very weak value last January). For January, new home construction in Rhode I sland was essentially non-existent! The good news here is that this will help keep our stock of unsold homes down.

The list of non-improving indicators should be all too familiar by now. Retail Sales fell by 3.3 percent, while US Consumer Sentiment also dropped sharply (by $22.1 \%$ ). Both have declined for the last twelve months. Employment Service Jobs, a leading labor market indicator that includes "temps," continued its string of double-digit declines that began last July, falling by 22.3 percent. Private Service-Producing Employment declined by 2.7 percent, and Government Employment fell by 2.3 percent. Ironically, the stimulus money should benefit Government Employment as we move through 2009 and into 2010.

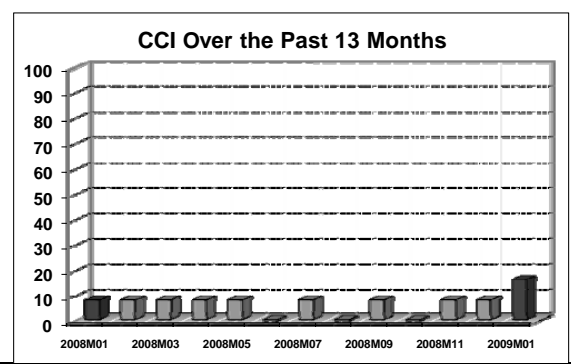

\section{THE BOTTOM LINE}

While Rhode Island may have survived what will be its most rapid rate of decline, ongoing deterioration in economic activity here will continue throughout all of this year. If I am correct that the rate of decline will moderate this year, then assuming that no "shoes" drop globally, things should eventually get more predictable and perhaps tolerable as we move toward the end of this year. How adequately will we plan for our future?

\begin{tabular}{|c|c|c|c|c|c|c|c|c|c|c|c|c|}
\hline & Jan & Feb & Mar & Apr & May & $J$ un & Jul & Aug & Sep & Oct & Nov & Dec \\
\hline 2008 & 8 & 8 & 8 & 8 & 8 & 0 & 8 & 0 & 8 & $0 \downarrow$ & 8 & 8 \\
\hline 2009 & 17 & & & & & & & & & & & \\
\hline
\end{tabular}

